\title{
Erratum: Fission and fusion scenarios for magnetic microswimmer clusters
}

\author{
Francisca Guzmán-Lastra, Andreas Kaiser \& Hartmut Löwen
}

Nature Communications 7:13519 doi:10.1038/ncomms13519 (2016); Published 22 Nov 2016; Updated 17 Jan 2017

This Article contains an error in Reference 18 that was introduced during the production process. The correct reference should be:

Steinbach, G. et al. Stirrers and movers actuated by oscillating fields. Preprint at arXiv:1607.04733 (2016).

Reference 18 should have been cited in the second paragraph of the 'Discussion' section as follows: 'For magnetic dipoles it has been shown that the actuation by an oscillating external magnetic field enables the propulsion of structurally non-deforming chains and rings up to $N=5$ particles ${ }^{18}$.' and 'The recent experimental developments provide evidence that our predictions about fission and fusion can be verified in granular and colloidal magnetic swimmers ${ }^{14,18,25}$ as well as in magnetotactic bacteria ${ }^{56-58}$..

(c) (i) This work is licensed under a Creative Commons Attribution 4.0 International License. The images or other third party material in this article are included in the article's Creative Commons license, unless indicated otherwise in the credit line; if the material is not included under the Creative Commons license, users will need to obtain permission from the license holder to reproduce the material. To view a copy of this license, visit http://creativecommons.org/licenses/by/4.0/

(C) The Author(s) 2017 